\title{
Действие двухвалентных катионов металлов на функционирование НАДФ+-зависимой малатдегидрогеназы из листьев кукурузы
}

\author{
(C) 2020 Гатауллина M.О., Епринцев А.Т. \\ ФГБОУ ВО «Воронежский государственный университет», Воронеж
}

Поступила в редакцию 05.02.2020 г.

DOI: $10.17308 /$ sorpchrom.2020.20/2872

Малатдегидрогеназа (МДГ, НАДФ-зависимая оксидоредуктаза, КФ 1.1.1.82) - НАДФ+-МДГ (КФ 1.1.1.82) является важным ферментом, метаболизирующим органические кислоты растений. Целью данной работы являлось определение таких регуляторных свойств энзима как влияение двухвалентных металлов на его активность.

В качестве объекта исследования использовали листья 10-дневных проростков кукурузы. Разделение тканей проводили по методу Клечковского. Очистка фермента была проведена классическим методом. В качестве исследуемых ионов брались хлориды таких двухвалентных катионов металлов как магний, кальций, барий и марганец.

Таким образом, четырех стадийная очистка, включающая в себя гомогенизацию, фракционирование сульфатом аммония, гель-фильтрацию на сефадексе G-25 и ионообменную хроматографию на ДЭАЭ-Sephacel, позволила получить высокоочищенные препараты НАДФ ${ }^{+}$-малатдегидрогеназы из мезофилла листьев кукурузы. При этом степень очистки выросла в 57 раз, а процент выхода исследуемого белка от общего равнялся 6\%. Удельная активность очищенной НАД $\Phi^{+}$-зависимой малатдегидрогеназы при пересчете на миллиграмм белка составила 91 ферментативную единицу.

При универсальном окрашивании нитратом серебра и специфическом окрашивании тетразолиевым методом полиакриламидного геля, полученного после электрофореза очищенной МДГ, была обнаружена только одна белковая полоса, что свидетельствует о гомогенности очищенного препарата малатдегидрогеназы.

Исследование влияния катионов различных металлов позволило выявить их действие на функционирование малатдегидрогеназы. Было изучено влияние хлоридов ионов $\mathrm{Mg}^{2+}, \mathrm{Mn}^{2+}, \mathrm{Ba}^{2+}$, $\mathrm{Ca}^{2+}$ на активность очищенного препарата. Показано, что магний в небольших концентрациях (до 3 мМ) активирует НАД $\Phi^{+}$-зависимый МДГ. Марганец и барий, напротив, ингибируют фермент. Ионы кальция не оказывали влияния на активность МДГ. Анализ полученных данных, осуществленный с помощью графиков Лайнуивера-Берка, позволил установить наличие разных типов ингибирования. Конкурентный тип ингибирования характерен для действия катионов марганца. Для катионов бария выявлен бесконкурентный тип торможения работы фермента.

Ключевые слова: НАД $\Phi^{+}$-малатдегидрогеназа, Zea mays, мезофилл, ионообменная хроматография, электрофорез, двухвалентные металлы.

\section{Введение}

Малатдегидрогеназа (МДГ, НАДФ-зависимая оксидоредуктаза, КФ 1.1.1.82) НАД $\Phi^{+}-$МГГ (КФ 1.1.1.82) катализирует обратимое превращение оксалоацетата в малат с использованием НАДФН в качестве кофактора [1]. Данный фермент является важным биокатализатором метаболизма яблочной кислоты в растительных клетках. При этом обеспечивается необходимый энергетический потенциал коферментов в форме НАДФН ${ }^{+}[1]$. 
Малат, образующийся в ходе реакции НАДФН-МДГ в клетках мезофилла С4растений, транспортируется в хлоропласты клеток обкладки и участвует в обеспечении донора $\mathrm{CO}_{2}$ для механизма концентрации углерода. Известно, что активность

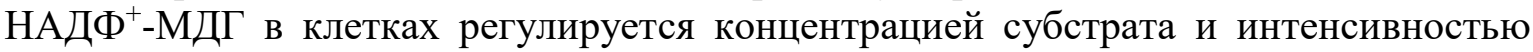
света и в несколько раз ниже у С3-растений по сравнению с С4-видами [2]. Кроме того, на активность ферментов могут влиять такие факторы как температура, $\mathrm{pH}$ и концентрация различных катионов [3].

Ионы различных металлов также могут осуществлять регуляцию активности ферментов путем их взаимодействия с активным центром фермента. При этом одни ионы активируют работу ферментов, другие же ингибируют [4-6]. В связи с этим, целью данной работы являлось определение регуляторных свойств малатдегидроге-

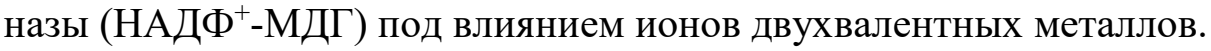

\section{Экспериментальная часть}

Объектом исследования являлись 10-ти дневные проростки кукурузы (Zea mays L., сорта Воронежская 76), выращенные гидропонным методом при $25^{\circ} \mathrm{C}$. Активность МДГ измеряли по изменению оптической плотности реакционной смеси, определяемой скоростью образования или расходования НАДФН, спектрофотометрически при 340 нм на СФ-2000 («Ломо», Россия). Среда при определении скорости восстановления оксалоацетата содержала 100 мМ трис-HCl буфер, $\mathrm{pH}$ 8.0, 1.5 мМ оксалоацетат; 0.15 мМ НАДФН. Активность МДГ в прямой реакции определяли в реакционной среде, содержавшей 100 мМ трис- $\mathrm{HCl}$ буфер, $\mathrm{pH} 8.0,4$ мМ малата и 1 мМ НАД ${ }^{+}$.

За единицу ферментативной активности МДГ принимали количество фермента, которое превращало (для обратной реакции) или образовывало (для прямой реакции) 1 мкмоль НАДФН за 1 мин при $25^{\circ} \mathrm{C}$.

Очистку проводили в четыре этапа. На первом этапе отделяли мезофильную ткань методом Клечковского [7], после чего ее гомогенизировали. Далее проводили высаливание сульфатом аммония в концентрации от 25 до 80\%. Низкомолекулярные примеси отделяли на колонке $(1.5 \times 20$ см) с сефадексом G-25 («Pharmacia», Швеция). Фракцию, содержащую фермент, подвергали ионообменной хроматографии на колонке (1.5x12 см) с ДЭАЭ-Sephacel («GEHealthcare», Швеция). Элюцию проводили линейным градиентом $\mathrm{NaCl}$ (0-150 мМ), собирая фракции с малатдегидрогеназной активностью.

Электрофорез в 7\%-ном полиакриламидном геле проводили по методу Дэвиса. Гель окрашивали нитратом серебра [8]. Специфическое проявление МДГ осуществляли тетразолиевым методом. Для этого гель инкубировали в темноте при $37^{\circ} \mathrm{C}$ в среде, содержавшей 100 мМ трис-HCl-буфер, $\mathrm{pH} 8.0,2 \mathrm{M}$ раствор малата натрия, 18 мг НАД $\Phi^{+}, 10$ мг нитросинего тетразолия (предварительно растворенного в $0.5 \mathrm{~cm}^{3}$ этиленгликоля) и 0.6 мг феназинметасульфата. Содержание белка определяли по методу Лоури [9].

Действие ионов двухвалентных металлов на активность МДГ проводили для хлоридов кальция, бария, марганца и магния. Используемые в опытах катионы добавлялись в концентрации от 0,05 до 40 мМ в реакционную среду.

Опыты проводили в 3-4-кратной повторности, аналитические определения для каждой пробы осуществляли в трех повторностях. Критерий Стьюдента использовался с применением поправки Бонферрони на множественные сравнения. Дополнительно применялся однофакторный дисперсионный анализ ANOVA, который по- 
казал, что исследуемый в работе фактор действительно оказывал влияние (влияние фактора достоверно при р<0.05).

\section{Обсуждение результатов}

НАД $\Phi^{+}$-зависимая оксидоредуцирующая малатдегидрогеназа в мезофильной ткани имеет всего одну изоформу, характеризующуюся относительной электрофоретической подвижностью $\left(\mathrm{R}_{\mathrm{f}}=0.4\right)$. Данная форма фермента была очищена и исследована его регуляция двухвалентными катионами.

После четырехстадийной очистки был получен препарат, удельная активность которого составила 91 Е/мг белка, степень очистки - 57 и выход - 6\% (табл.1.). Для получения высокоочищенной МДГ использовали ионообменную хроматографию на ДЭАЭ-Sephacel $[10,11]$. Максимальное количество фермента десорбировалось при элюции $96 \mathrm{мM} \mathrm{NaCl}$.

Таблица 1. Этапы очистки НАДФ ${ }^{+}$-зависимой малатдегидрогеназы из мезофилла кукурузы $(\mathrm{n}=3, \mathrm{p} \leq 0.05)$

\begin{tabular}{|c|c|c|c|c|c|c|}
\hline Стадия & $\mathrm{V}, \mathrm{cm}^{3}$ & $\begin{array}{c}\text { Белок, } \\
\text { мг }\end{array}$ & $\begin{array}{c}\text { Общая ак- } \\
\text { тивность, } \\
\text { Е. }\end{array}$ & $\begin{array}{c}\text { Удельная } \\
\text { активность } \\
\text { Е/мг белка }\end{array}$ & $\begin{array}{c}\text { Выход, } \\
\%\end{array}$ & $\begin{array}{c}\text { Степень } \\
\text { очистки }\end{array}$ \\
\hline 1. Гомогенат & 10 & 73.4 & 118 & 1.6 & 100 & 1 \\
\hline $\begin{array}{c}\text { 2. Фракциониро- } \\
\text { вание солями }\end{array}$ & 1 & 10.3 & 23.6 & 2.2 & 20 & 1.3 \\
\hline $\begin{array}{c}\text { 3. Гель- } \\
\text { фильтрация через } \\
\text { сефадекс G-25 }\end{array}$ & 6 & 9.6 & 21.8 & 2.3 & 18.4 & 1.3 \\
\hline $\begin{array}{c}\text { 4. Ионообменная } \\
\text { хроматография на } \\
\text { ДЭАЭ-SЕРНАСЕL }\end{array}$ & 3 & 0.08 & 7.3 & 91 & 6 & 57 \\
\hline
\end{tabular}

При универсальном окрашивании нитратом серебра и специфическом окрашивании тетразолиевым методом полиакриламидного геля, полученного после электрофореза очищенной МДГ, была обнаружена только одна белковая полоса, что свидетельствует о гомогенности очищенного препарата малатдегидрогеназы (рис.1).
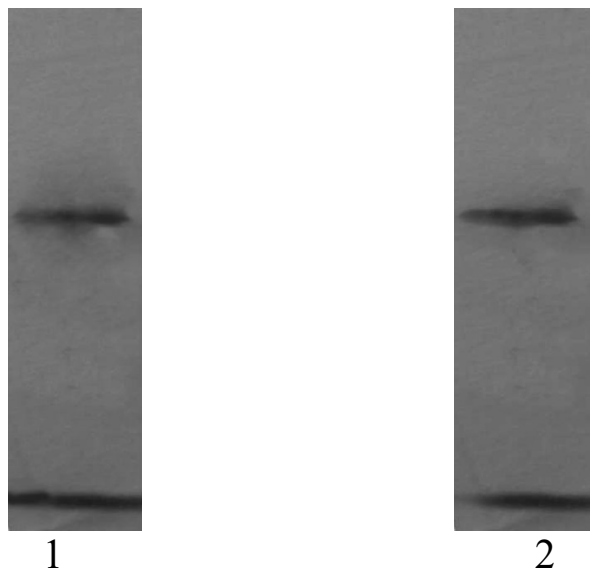

Рис. 1. Определение гомогенности очищенного препарата НАДФ-МДГ с помощью электрофореза: 1 - универсальное проявление белков нитратом серебра; 2 -- специфическое проявление МДГ тетразолиевым методом 
Ионы металлов играют важную роль в метаболизме всех живых организмов. Одни катионы являются для энзимов необходимыми коферментами [12-14], без которых невозможно протекание реакции. Другие, в том числе тяжелые металлы, загрязнение которыми вызывает определенные опасения, ингибируют эти процессы $[15,16]$.

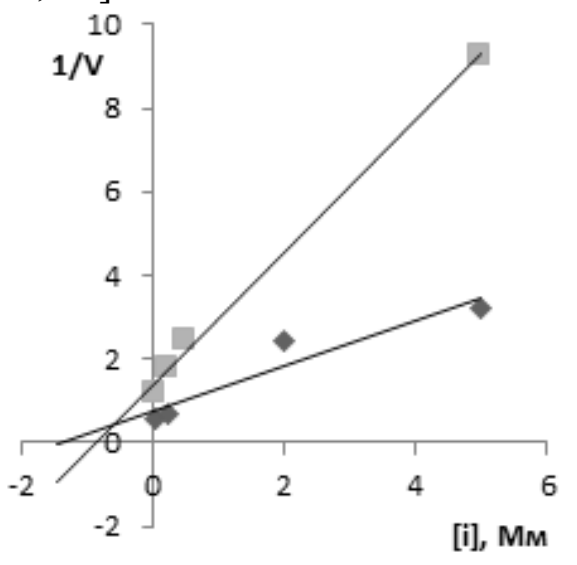

Рис. 2. Влияние ионов магния до

$5 \mathrm{MM} \mathrm{на} \mathrm{активность} \mathrm{препаратов}$ НАДФ-МДГ при концентрации субстрата: $1-0.1$ мМ малат; $2-0.2$ мМ малат

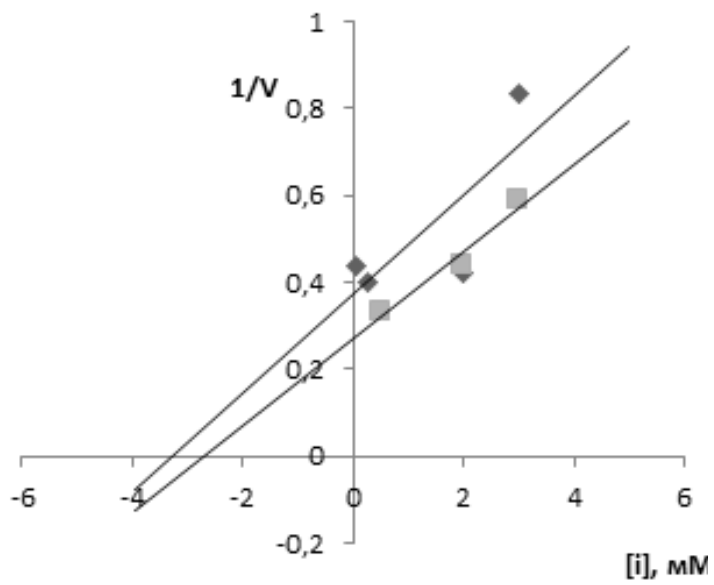

Рис. 4. Влияние ионов бария на активность препаратов НАДФ-МДГ при концентрации субстрата: $1-0.1 \mathrm{мM}$ малат; 2-0.2 мМ малат

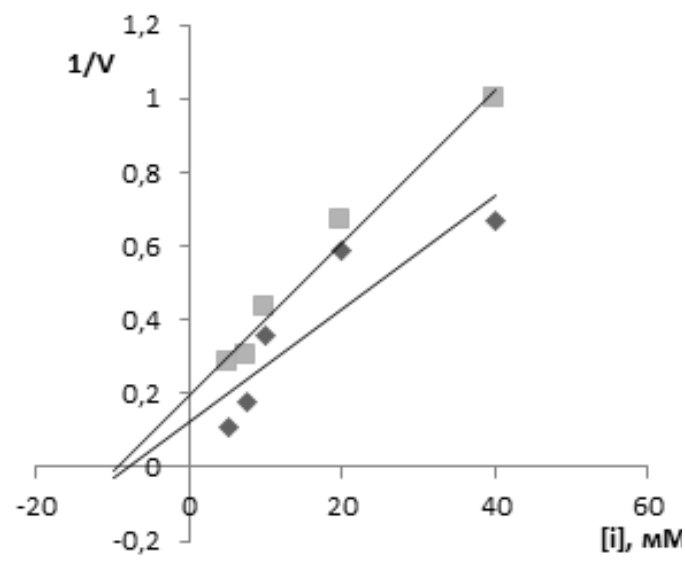

Рис. 3. Влияние ионов магния более 5мМ на активность препаратов НАДФ-МДГ при концентрации субстрата: $1-0.1$ мМ малат; $2-0.2$ мМ малат

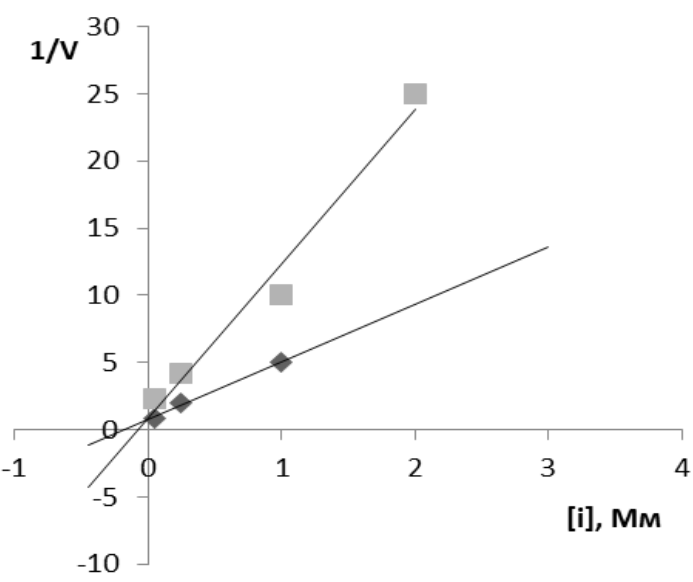

Рис. 5. Влияние ионов марганца на активность препаратов НАДФ-МДГ при концентрации субстрата: $1-0.1$ мМ малат; 2-0.2 мМ малат.

Было исследовано влияние хлоридов ионов $\mathrm{Mg}^{2+}, \mathrm{Mn}^{2+}, \mathrm{Ba}^{2+}, \mathrm{Ca}^{2+}$ на активность очищенного препарата. Показано, что магний в небольших концентрациях (до 3 мМ) активирует НАД ${ }^{+}$-зависимый МДГ (рис.2.). Марганец и барий, напротив, ингибируют фермент (рис. 3-5). Ионы кальция не оказывали влияния на активность МДГ. Анализ полученных данных, осуществленный с помощью графиков Лайнуивера-Берка, позволил установить наличие разных типов ингибирования. Конкурентный тип ингибирования характерен для действия катионов марганца. Этот тип торможения работы фермента свидетельствует о важной роли этих катионов в работе активного центра малатдегидрогеназы [17]. Повышение концентрации субстрата, как правило, обеспечивает снижение тормозящего действия ингибитора. Для катионов бария выявлен бесконкурентный тип торможения работы фермента (рис.1,4). 
При данном типе ингибирования образование комплекса с субстратом не изменяет конформацию фермента, взаимодействие комплекса с ингибитором должно осуществляться, по крайней мере частично, при участии связанного субстрата [18].

\section{Заключение}

Четырехстадийная очистка, включающая в себя ионообменную хроматографию на ДЭАЭ-Sephacel, позволила получить высокоочищенные препараты НАД $\Phi^{+}-$ малатдегидрогеназы из мезофилла листьев кукурузы. Исследование влияния катионов различных металлов позволило выявить их действие на функционирование малатдегидрогеназы. Установлен различный механизм торможения активности МДГ различными катионами металлов. При этом выявлено конкурентное ингибирование функционирования НАД ${ }^{+}$-малатдегидрогеназы для катионов марганца и бесконкурентное торможение для ионов бария.

Работа выполнена при поддержке Министерства науки и высшего образования РФ в рамках государственного задания ВУЗам в сфере научной деятельности на 2020-2022 годы, проект № FZGU-2020-0044»

\section{Список литературы}

1. Комов В.П., Шведова В.Н., Биохимия. М. Юрайт. 2015. 640 с.

2. Мамушина Н.С., Зубкова Е.К. // Ботанический журнал. 2005. Т. 90. №. 11. С. 16411650.

3. Марри Р., Греннер Д., Мейес П., Родуэлл В. Биохимия человека: В 2-х томах. Т. 1. М. Мир. 1993. 384 с.

4. Минкина Т.М., Мотузова Г.В., Манджиева С.С., Назаренко О.Г. и др. // Научный журнал Российского НИИ проблем мелиораиии. 2011. №. 4.

5. Бедняков Д. А., Невалённая Л. А., Новинский В. Ю. // Вестник Астраханского государственного технического университета. Серия: Рьбное хозяйство. 2011. №. 2. C. 74-77.

6. Гатауллина М.О., Епринцев А.Т. // Сорбционные и хроматографические проuессы. 2018. Т. 18. №. 1. С. 111-117.

7. Епринцев А.Т., Гатауллина М.О., Лященко М.С. // Прикладная биохимия и микробиология. 2016. Т. 52. №. 4. С. 365-369.

8. Davis B.J. // Society for the study at the New York Academy of medicine. 1959. Vol. 24. pp. 112-118.

9. Lowry O.H. H.J. Rosebrough, A.H. Papp et al. // J. Biologi. 1951. Vol. 193. pp. 265-275.
10. Селеменев В.Ф., Славинская Г.В., Хохлов В. Ю., Иванов В.А. и др. Практикум по ионному обмену. Воронеж. ВГУ. 160 с.

11. Рудаков О.Б., Селеменев В.Ф. Физикохимические системы сорбат-сорбент-элюент в жидкостной хроматографии. Воронеж. ВГУ. 2003. страницы

12. Смирнов В. А., Климочкин Ю. Н. Витамины и коферменты. Самара: Самар. гос. техн. ун-т. 2008. 92 с.

13. Шлейкин А.Г., Скворцова Н.Н., Бландов Н.Н. Прикладная энзимология: учебное пособие. СПб. Университет ИТМО. 2019. $160 \mathrm{c}$.

14. Peers M.K., Toogood H.S., Heyes D.J., Mansell D. et al. // Catalysis science \& technology. 2016. Vol. 6. No 1. pp. 169-177.

15. Neneng L., Gunawan Y.E. // Journal of Tropical Life Science. 2018. Vol. 8. No 1. pp. 228158.

16. Ahmed K. B. A., Raman T., Veerappan A. // Materials Science and Engineering: $C$. 2016. Vol. 68. pp. 939-947.

17. Парфенова И.В. автореф. дис. канд. биолог. наук. Воронеж. 2011. 23 с.

18. Плакунов В.К., Николаев Ю.А. Основы динамической биохимии. М. Логос. 2010. $216 \mathrm{c}$. 


\title{
Effect of bivalent metal cations on the functioning of $\mathrm{NADPH}^{+}$-dependent malate dehydrogenase from corn leaves
}

\author{
(C) 2020 Gataullina M.O., Eprintsev A.T.
}

Voronezh State University, Voronezh

\begin{abstract}
Malate dehydrogenase (MDH, NADPH-denpendent oxidoreductase, EC 1.1.1.82) - NADPH ${ }^{+}-\mathrm{MDH}$ (EC 1.1.1.82) is an important enzyme responsible for the metabolization of organic plant acids. The aim of the study was to determine the regulatory properties of the enzyme such as the effect of bivalent metals on its activity.

10-day-old corn seedlings were chosen as the subject for the study. The Klechkowski method was used for the separation of tissues. Enzyme purification was carried out by a traditional method. Chlorides of such bivalent metal cations as magnesium, calcium, barium, and manganese were used as the studied ions.

Thus, four-stage purification, including homogenisation, fractionation with ammonium sulfate, elfiltration on Sephadex G-25, and ion-exchange chromatography on DEAE-Sephacel made it possible to obtain high purity $\mathrm{NADPH}^{+}$malate dehydrogenase from mesophyll of corn leaves. The degree of purification increased by 57 times and the yield of the studied protein was $6 \%$ of the total. The specific activity of the purified $\mathrm{NADPH}^{+}$-dependent malate dehydrogenase in terms of protein milligrams was 91 enzyme units.

Universal staining with silver nitrate and specific staining by tetrazolium method, polyacrylamide gel obtained as a result of electrophoresis of purified MDH revealed only one protein band which means that the purified malate dehydrogenase preparation was homogenous.

The study of the effect of cations of different metals allowed us to identify their effect on the functioning of malate dehydrogenase. The effect of chlorides of $\mathrm{Mg}^{2+}, \mathrm{Mn}^{2+}, \mathrm{Ba}^{2+}$, and $\mathrm{Ca}^{2+}$ ions on the activity of the purified preparation was studied. It was demonstrated that small concentrations of magnesium (within $3 \mathrm{mM}$ ) activates NADPH-denpendent MDH. Barium and manganese inhibit the enzyme. Calcium ions did not affect the MDH activity. The analysis of the obtained data by means of Lineweaver-Burk plots revealed different types of inhibition. Competitive inhibition is characteristic of manganese cations. Barium cations demonstrate incompetitive enzyme inhibition.
\end{abstract}

Keywords: $\mathrm{NADPH}^{+}$malate dehydrogenase, Zea mays, mesophyll, ion exchange chromatography, electrophoresis, bivalent metals

\section{References}

1. Komov V.P., Shvedova V.N., Biokhimija, M., Uright, 2015, 640 p.

2. Mamushina N.S., Zubkova E.K., Botanicheskij zhurnal, 2005, Vol. 90, No 11, pp. 16411650.

3. Marri R., Grenner D., Mejes P., Rodujell V. Biokhimija cheloveka, V 2-h tomah. Vol. 1, M., Mir, 1993, $384 \mathrm{p}$.

4. Minkina T.M., Motuzova G.V., Mandzhieva S.S., Nazarenko O.G. et al., Nauchnyj zhurnal Rossijskogo NII problem melioracii, 2011, No 4.

5. Bednjakov D.A., Nevaljonnaja L.A., Novinskij V.Ju., Vestnik Astrahanskogo gosudarstvennogo tehnicheskogo universiteta. Serija: Rybnoe hozjajstvo, 2011, No 2, pp. 74-77.

6. Gataullina M.O., Eprintsev A.T., Sorbtsionnye i khromatograficheskie protsessy, 2018, Vol. 18, No 1, pp. 111-117.

7. Eprincev A.T., Gataullina M.O., Ljashhenko M.S., Prikladnaja biohimija i mikrobiologija, 2016, Vol. 52, No 4, pp. 365-369.

8. Davis B.J., Ornstein L. Society for the study at the New York Academy of medicine. 1959. pp. 112-118.

9. Lowry O.H., Rosebrough H.J., Papp A.H. et al., J. Biologi, 1951, Vol. 193, pp. 265-275.

10. Selemenev V.F., Slavinskaya, G.V., Khokhlov V.Yu., Ivanov V.A. et al., Praktikum po ionnomu obmenu, Voronezh, VGU, 2004, $160 \mathrm{p}$.

11. Rudakov O.B., Selemenev V.F. Fizikohimicheskie sistemy sorbat-sorbent-jeljuent $\mathrm{V}$ zhidkostnoj hromatografii, Voronezh, VGU, 2003, $300 \mathrm{p}$.

12. Smirnov V.A., Klimochkin Ju.N. Vitaminy i kofermenty, Samara, Samar. gos. tehn. un-t, 2008, $92 \mathrm{p}$. 
13. Shlejkin A.G., Skvorcova N.N., Blandov N.N. Prikladnaya enzymologia: uchebnoeposobie. $\mathrm{SPb}$, Universitet ITMO, 2019. $160 \mathrm{p}$.

14. Peers M.K. Toogood H.S., Heye, D.J., Mansell D. et al., Catalysis science \& technology, 2016, Vol.6, No 1, pp.169-177.

15. Neneng L., Gunawan Y.E., Journal of Tropical Life Science, 2018, Vol. 8, No 1, pp. 228158.

Гатауллина Марина Олеговна - ассистент, кафедра биохимии и физиологии клетки, Воронежский государственный университет, Воронеж, тел.(473)2208877

Епринцев Александр Трофимович - д.б.н., проф., кафедра биохимии и физиологии клетки, Воронежский государственный университет, Воронеж, тел.(473)2208877
16. Ahmed K.B.A., Raman T., Veerappan A., Materials Science and Engineering: C, 2016, Vol. 68, pp. 939-947.

17. Parfenova I.V. avtoref. dis. kand. biolog.nauk. Voronezh, VGU, 2011, 23 p.

18. Plakunov V.K., Nikolaev Ju.A., Osnovy dinamicheskoj biohimii, M., Logos, 2010, 216p.

Gataullina Marina O.--assistent, Department of Biochemistry and Physiology, Voronezh State University, Voronezh, Email:marina.gataullina@gmail.com

Eprintsev Alexander T. - Doctor of Biology, Department of Biochemistry and Physiology, Voronezh State University, Voronezh E-mail: bc366@bio.vsu.ru 